\title{
Soft Tissue Pathology: Diagnostic Challenges
}

Editors

LEONA A. DOYLE

KAREN J. FRITCHIE

\section{SURGICAL PATHOLOGY CLINICS}

www.surgpath.theclinics.com

Consulting Editor

JOHN R. GOLDBLUM

September 2015 • Volume 8 • Number 3 